\title{
ROLE OF SHODHANA KARMA IN THE CONSERVATIVE MANAGEMENT OF VARICOSE ULCER: A CASE STUDY

\author{
Chaturvedi Ashutosh ${ }^{1}$, Shruthi S*1, M S Gayathry ${ }^{1}$, Ashvini Kumar M$^{2}$, Shetty Gautam² \\ ${ }^{1}$ PG Scholar, Department of PG Studies in Panchakarma, SDM College of Ayurveda \& Hospital, Hassan, \\ Karnataka, India
} \\ ${ }^{2}$ Associate professor, Department of PG Studies in Panchakarma, SDM College of Ayurveda \& Hospital, Hassan,
} Karnataka, India

Received on: 08/04/15 Revised on: 01/05/15 Accepted on: 02/06/15

\author{
*Corresponding author \\ Dr. Shruthi S, PG Scholar, Department of PG Studies in Panchakarma, SDM College of Ayurveda \& Hospital, Hassan, Karnataka, India \\ E-mail: shruthiprabha26@gmail.com
}

DOI: $10.7897 / 2277-4343.06487$

\begin{abstract}
Venous ulcers are responsible for lost work productivity and high health-care costs. Contemporary science has initial treatment of venous ulcers targets the underlying cause. Venous Ulcer are costly to treat in comparison to traditional system, and there is a significant chance that they will reoccur after healing; one study found that up to $48 \%$ of venous ulcer had recurred by the fifth year after healing. Male patient aged 29 year with complaints pain and dilated torturous vein in bilateral leg below knee pain which was increase during night hours and on long standing with virechana karma. After the whole course of therapy it was found significant relief in signs and symptoms of varicose ulcer. The therapy provided marked relief in pain, tenderness, wound healing, change in skin pigmentation and hardening of skin. Conservative management of Varicose Ulcer through Ayurvedic Principle provides significant relief and improves quality of life.
\end{abstract}

Key words: Varicose ulcer; Panchakarma; Virechana karma

\section{INTRODUCTION}

Varicose veins affect a significant percentage of population in the society. They may not cause mortality but are a cause of considerable morbidity if not properly treated. Varicose Ulcer is diagnosed based on the basis of CEAP classification considers the clinical, etiologic, anatomic, and pathologic characteristics of venous insufficiency, ranging from class 0 (no visible sign of disease) to class 6 (active ulceration). ${ }^{1}$ In present case patient having C2 (Varicose veins), C4a (Pigmentation), Es: secondary, as: superficial veins, Pr: reflux

Varicose Ulcer is the wound that are thought to occur due to improper functioning of the venous valves, usually of leg. They are the major occurrence of chronic wound occurring in 70 to $90 \%$ of leg ulcer cases. Venous ulcers develop mostly along the medial distal leg and can be very painful. Venous Ulcer are costly to treat, and there is a significant chance that they will reoccur after healing; one study found that up to $48 \%$ of venous ulcer had recurred by the fifth year after healing. ${ }^{2}$ Venous ulcers are responsible for lost work productivity and high healthcare costs. Contemporary science has initial treatment of venous ulcers targets the underlying cause of CVD (venous obstruction, reflux, or a combination of obstruction and reflux), Compression therapy, Skin grafts, Surgery. Many Treatments are praised in the management of Varicose Ulcer based on stages of disease. Whereas Ayurveda provides the conservative line of management which helps in improving quality of life.

\section{CASE DETAILS}

A 29 years old male reported to Panchakarma OPD (Ethical clearance number: SDMCAH/RD2015-1505), SDM College of Ayurveda and hospital Hassan with complaints of pricking type pain and dilated torturous vein in both leg below knee and wound in left medial malleolus since 4 years. Patient was apparently alright 4 years back. Gradually developed pain and dilated torturous vein in bilateral leg below knee pain which was increase during night hours and on long standing. Since 3 years he developed wound in medial malleolus of left leg. For which he consulted a hospital at Bengaluru he advise with some pain killer felt temporary relief. He used to get temporary relief only on taking pain killer if he stop taking pain killer the pain remains same, so he was advised for Doppler and diagnosed as Sapheno-femoral Junction Incompetent. After this episode he consulted same doctor for which he advised to undergo the same treatment and suggested for surgical intervention. To avoid surgical intervention and for conservative and better treatment he approach to our hospital. When he approached to the physician he overall had pricking pain and dilated torturous vein in both leg below knee and wound in left medial malleolus.

On examination was present with visible, dilated torturous vein in both leg below knee, Third degree of tenderness over both legs, Wound on left medial Malleolus region discoloration and darkening of the skin around the ulcer hardened skin around the ulcer. 
Considering the history and examination patient was planned to post Virechana Karma. Patient was administered with Panchakola Phanta ${ }^{3} 50 \mathrm{ml}$ twice a day and Chitrakadi vati ${ }^{4} 2$ tablets thrice daily before food for three consecutive days as Deepana Pachana. In mean time patient was administered with Sthanika Parisheka ${ }^{5}$ with Panchavalakala Qwatha ${ }^{6}$ for three consecutive days. After three days, patient attained Samyak Pachana Lakshana later posted for Arohana Shodhana Purava Sneha with MahaTiktaka $\mathrm{Grita}^{7}$ for 5 consecutive days with initial dosage of $30 \mathrm{ml}$ then raised to $60 \mathrm{ml}, 100 \mathrm{ml}, 140 \mathrm{ml}, 180 \mathrm{ml}$ on second, third and fouth day respectively. Patient advised with Sarvanga Abhyanga and Bashpa Sweda for next 3 days. Three days Vishrama kala was given during which patient was administered with Pitta Utkleshakara Ahara like Laghu Bhojana, Amla phala Rasa, Ushna Udaka will help to alleviate Pitta Dosha and will help for
Kapha Avrudhhikara. Next day patient was posted for Virechana Karma $^{8}$ with Trivrit lehya ${ }^{9} 70$ gm with Draksha Kashaya ${ }^{10} 100 \mathrm{ml}$ as Anupana. Patient had 18 vega with kaphanata and attained Madhyama Langiki Shuddhi. Patient was observed for complication whole day. No untoward complications were observed. Later patient was advised to follow Samsarjana Karma. Pathya $^{11}$ was advised with smoking cessation and during the course of treatment. During the course of Deepana Pachana patient was not found with any significant relief however Improvement was present at the course of Virechana therapy in Pain, Wound and Skin discoloration. Overall symptomatically subject felt $60 \%$ better. On discharge is advised with Kaishore Guggulu two twice a day and Maha Manjistadi Kashaya $15 \mathrm{ml}$ TID with $30 \mathrm{ml}$ of hot water before food.

Table 1: Comparison of symptoms

\begin{tabular}{|c|c|c|c|c|}
\hline Symptoms & Before Treatment & After Snehapana & After Shodhana & After samsarjana karma \\
\hline Pain & ++++ & +++ & + & - \\
\hline Tenderness & Grade 3 & Grade 3 & Grade 0 & Grade 0 \\
\hline Varicose vein & Present & Present & Present & Present \\
\hline Ulcer & Unhealed & Unhealed & Healed & Healed \\
\hline Color Change & Blackish & Blackish & Pinkish & Skin color \\
\hline
\end{tabular}

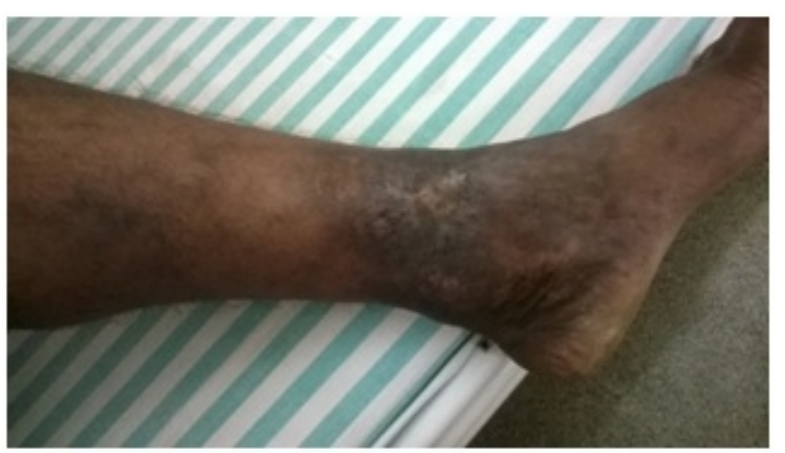

Figure 1: Varicose ulcer before treatment

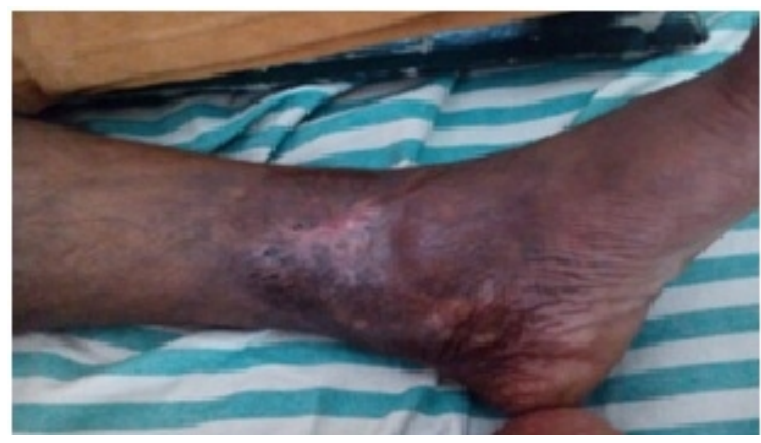

Figure 3: Varicose ulcer After Virechana

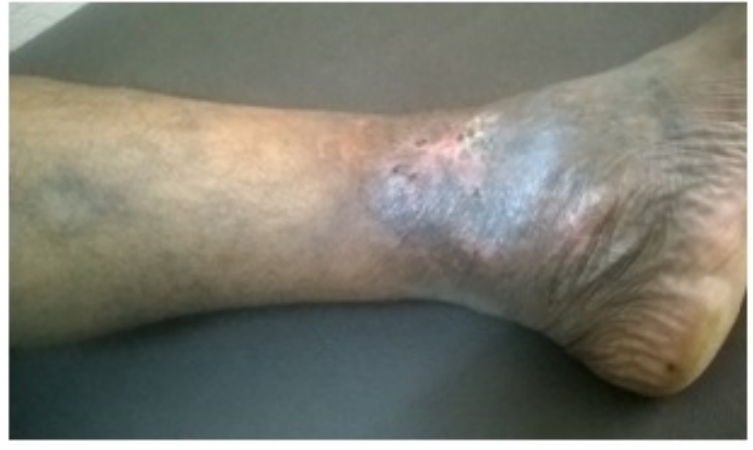

Figure 2: Varicose ulcer After Snehapana

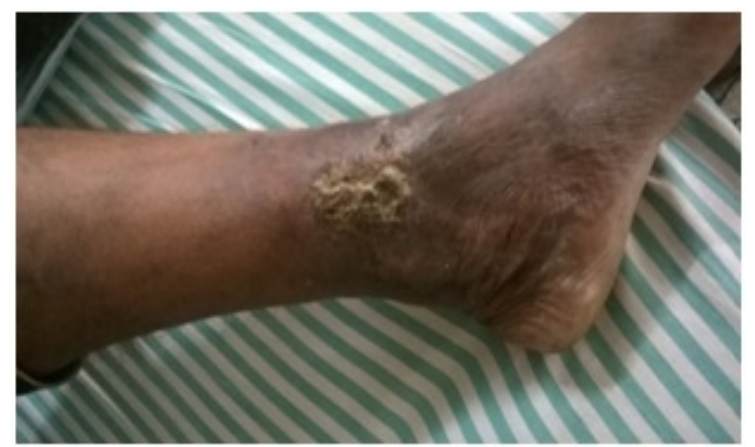

Figure 4: Varicose ulcer After Samsarjana Krama 


\section{DISCUSSION}

By considering the Sign and Symptoms, there is involvement of Pitta and Rakta dosha. The Patient had predominate symptom's like of pricking type pain (Vata and Pitta) and dilated torturous vein in both leg below knee (involvement of Sira which is the upadhatu of Rakta), Wound (vata and pitta) and Skin changes(vata, Pitta ,Rakta and Mamsa) . Virechana karma is selected due to involvement of Pitta, Rakta and Vata in this particular case. So Bahya Rukshana and Abhyantara Rukshana were selected as initial line of treatment. Externally Parisheka was carried out with Panchavalakala qwatha as it is indicated in "Anyatarsmin Pittasamsrushte Drava sweda and Vrana Rujapaha. Internal rukshana was done with Pachana daravya as Deepana and Pachana Dravyas are administered for the correction of Agni and the dosha must be balanced and metabolic toxin must be eliminated from dhatus through Panchakarma. Pachana dravaya are also explained as a variety of rukshana, MahaTikthaka Gritha is selected for Snehapana as it is indicated in Pitta vikara, Ruk, Twak vikara and Vrana. In this condition Vrana line of treatment is adopted i.e. Avasechana as per Doshik involment , So Virechana karma selected for elimination of Pitta and Rakta Dosha, Vata Anulomana action and to increase the Healing process of vrana i.e Vrana ropanartha. As sira is a upadhatu of Rakta Virechana Karma helps in wound healing. The results were encouraging. The therapy provided marked relief in pain, tenderness, wound healing, change in skin pigmentation and hardening of skin. Conservative management of Varicose Ulcer through Ayurvedic Principle provides significant relief and improves quality of life.

\section{REFERENCES}

1. Snyder RJ. Treatment of nonhealing ulcers with allografts. Clin. Dermatol. $2005 ; 23(4): 388-95$ http://dx.doi.org/10.1016/j.clindermatol.2004.07.020

2. Brem H, Kirsner RS, Falanga V. Protocol for the successful nonsurgical treatment of venous ulcers. Am. J. Surg. 2004;188(1A Suppl): $1-8$.

3. Sharangadhara, Sharangadhara Samhita with Commentaries Adhamallas Dipika and Kasiramas Gudhartha Dipika, Published by Choukhabha orientalia, Varanasi. Madhyama Khanda, 4/6 p.91

4. Agnivesha. Charaka Samhita, redacted by Charaka and Dridhabala, Ayurvedadipika commentary of Chakrapanidatta, edited by Yadavjitrikamji, Varanasi Chaukhambha orientalia, Varanasi, U.P. 2011; p. 622

5. Sushruta, Sushruta Samhita with Nibandha Sangraha commentary Choukhamba Sanskrit series 2002, Chikitsa Sthana, 33/36 p.248

6. Sharangadhara, Sharangadhara Samhita with Commentaries Adhamallas Dipika and Kasiramas Gudhartha Dipika, Published by Choukhabha orientalia, Varanasi. Madhyama Khanda, 4/6 p. 91

7. Agnivesha. Charaka Samhita, redacted by charaka and Dridhabala,Ayurvedadipika commentary of Chakrapanidatta, edited by Yadavjitrikamji, Varanasi Chaukhambha orientalia, Varanasi, U.P. 2011; p .622

8. Vagbhata; Astanga Hridaya with vidyotini commentary, Choukambha publication, Varanasi 2000. Sutra Sthana 12/9 p. 98

9. Agnivesha. Charaka Samhita, redacted by charaka and Dridhabala, Ayurvedadipika commentary of Chakrapanidatta, edited by Yadavjitrikamji, Varanasi Chaukhambha orientalia, Varanasi, U.P. 2011 p. 421

10. Sharangadhara, Sharangadhara Samhita with Commentaries Adhamallas Dipika and Kasiramas Gudhartha Dipika, Published by Choukhabha orientalia, Varanasi. Madhyama Khanda, 4/6 p . 172

11. S Shruthi, Bhattacharyya Nirupam, Shetty Gautham, M Ashvini Kumar, Pujar Muralidhar P. Role of pathya apathya in panchakarma: A critical review. Int. J. Res. Ayurveda Pharm. 2014;5(3):390 -393 http://dx.doi.org/10.7897/2277-4343.05380

\section{Cite this article as:}

Chaturvedi Ashutosh, Shruthi S, M S Gayathry, Ashvini kumar M, Shetty Gautam. Role of shodhana karma in the conservative management of varicose ulcer: A case study. Int. J. Res. Ayurveda Pharm. 2015;6(4):452-454 http://dx.doi.org/10.7897/2277-4343.06487

Disclaimer: IJRAP is solely owned by Moksha Publishing House - A non-profit publishing house, dedicated to publish quality research, while every effort has been taken to verify the accuracy of the content published in our Journal. IJRAP cannot accept any responsibility or liability for the site content and articles published. The views expressed in articles by our contributing authors are not necessarily those of IJRAP editor or editorial board members. 